Formatif: Jurnal Ilmiah Pendidikan MIPA

Vol. 9, No. 4, December 2019, pp. 339-352

p-ISSN: 2088-351X

e-ISSN: 2502-5457

DOI: http://dx.doi.org/10.30998/formatif.v9i4.4140

\title{
Enhanced Naturalist Intelligence in Early Childhood through Science Fiction Stories
}

\author{
Peningkatan Kecerdasan Naturalis Anak Usia Dini Melalui Cerita Fiksi Sains
}

\author{
Murtafiah \\ Universitas Negeri Jakarta \\ Zarina Akbar \\ Universitas Negeri Jakarta \\ Karnadi \\ Universitas Negeri Jakarta
}

Received: July 18, 2019

Revised: December 02, 2019

Accepted: December 02, 2019

\begin{abstract}
The purpose of this research is to describe the process and the result of the increase of natural intelligence in early childhood B1 RA Asy-Syafi` Kota Tangerang 2018-2019 through research and development science fiction method. The subjects of this study were 12 children. This research method is based on Action Research model of Kemmis and Mc Taggart which includes four stages: planning, action and observation, reflection. This action study was conducted in two cycles and each cycle consisted of 6 meetings. The data collected used in this action research are interviews, observation and documentation. Data analysis technique used in this research is qualitative and quantitative. The result showed that the increased natural intelligence of early childhood RA Asy-Syafi` Kota Tangerang 2018-2019 through science fiction method. The rate of development of focused attention obtained by early childhood in pre cycle is $42,50 \%$. In the first cycle the score is $68,50 \%$ and the second cycle is $86,33 \%$. This research reveals that research and development science fiction method is one solution to increase of natural intelligence early childhood.
\end{abstract}

Keywords: Natural Intelligence, Science Fiction, Early Childhood

(*) Corresponding Author: $\quad$ murtafiah59@yahoo.co.id

How to Cite: Murtafiah, M., Akbar, Z., \& Karnadi, K. (2019). Enhanced naturalist intelligence in early childhood through science fiction stories. Formatif: Jurnal Ilmiah Pendidikan MIPA, 9 (4): 339-352. http://dx.doi.org/10.30998/formatif.v9i4.4140

\section{PENDAHULUAN}

Dalam kehidupan keseharian anak, interaksinya dengan tanaman, hewan, dan lingkungan sekitar adalah hal yang biasa. Anak-anak sangat suka berada di mana anak dapat belajar mengenal alam, berkebun, dan bermain dengan binatang. Menggali tanah bisa jadi merupakan hobi yang menyenangkan bagi mereka untuk belajar dari alam dan hal ini merupakan pengetahuan yang luar biasa bagi anak. Pergeseran budaya dimana anak lebih suka bermain dengn gawai menyebabkan anak semakin jauh dengn alam. Sehingga perlu pembelajaran dan upaya yang dapat mendekatkan anak dengan alam. 
Pemahaman dan interaksi dengan alam akan menanamkan rasa sayang akan alam sekitar sehingga diharapkan terjaganya kelestarian alam sekitar. Pemahaman dan pembelajaran akan kecintaan dengan alam sekitar harus dimulai sejak dini.

Interaksi dengan lingkungannya adalah pembelajaran yang sangat menyenangkan bagi anak. Baum, Viens dan Slatin menuliskan, "Naturalist intelligence designates the human ability to discriminate among living things (plant, animal) as well as sensitivity to other features of the nature world (clouds, rock convigurations)" (Baum, Susan, Julie Viens, 2012). Kecerdasan naturalis adalah kecerdasan membedakan tanaman dan hewan serta benda di sekitar seperti awan, batu, dan sebagainya. Jadi pada pokoknya kecerdasan naturalis adalah kemampuan untuk mengenal tanaman, hewan, dan benda di sekitarnya.

Kiewra dan Veselack melakukan penelitian bahwa berinteraksi dengan alam pada anak usia dini mampu mendukung kreativitas dan imajinasi anak serta kemampuan memecahkan masalah, kecerdikkan, dan konstruksi. Planet bumi membutuhkan orang yang mampu memecahkan masalah, beradaptasi dengan situasi, dan berkomunikasi efektif (Kiewra \& Veselack, 2016). Karenanya pengalaman kreatif pada anak usia dini dapat dilakukan salah satunya dengan interaksi di ruang kelas terbuka alami.

Salah satu bentuk pembelajaran untuk anak usia dini adalah bercerita. Bercerita menurut Papadimitriou et al., adalah budaya global yang menggambarkan cara hidup dan berinteraksi dalam kehidupan. Terutama dalam bercerita anak usia dini muncul secara alami dalam permainan anak-anak yang membantu mereka untuk melakukan berbagai macam keterampilan (Papadimitriou, Kapaniaris, Zisiadis, \& Kalogirou, 2013). Bercerita merupakan cerminan budaya dan pembelajaran AUD.

Menurut Nurgiantoro anak membutuhkan informasi tentang dunia dan segala sesuatu yang ada dan terjadi di lingkungan sekelilingnya, seperti tanaman, hewan, dan sekitarnya. Pemenuhan kebutuhan anak akan informasi tersebut dapat diberikan lewat cerita (Nurgiyantoro, 2004). Selanjutnya Nurgiantoro mengatakan bahwa cerita fiksi sains adalah khas cerita anak yang mengandung unsur sains dan fiksi. Ditambahkan Rampan bahwa cerita fiksi sains (science fiction) atau sering disebut dengan fiksi ilmiah memiliki kelebihan yaitu merupakan bacaan yang amat digemari, terutama karena fiksi ilmiah secara kuat dan inovatif memberikan inspirasi kepada pembacanya, terutama disebabkan fantasinya yang begitu jauh dan kreatif (Rampan, 1999). Dengan demikian cerita fiksi sains merupakan cerita yang disuguhkan selain berisi fantasi juga memberikan inspirasi dan pengetahuan ilmiah (sains) bagi anak.

Salah satu media pembelajaran yang dapat digunakan guru untuk meningkatkan kecerdasan naturalis pada anak adalah cerita fiksi sains (science fiction), yang merupakan media pembelajaran berbentuk grafis berisi materi pembelajaran sains dan temanya disesuaikan dengan upaya peningkatan kecerdasan naturalis yang dikemas dalam sebuah alur cerita secara menarik. Cerita Fiksi sains (science fiction) adalah sebuah fiksi yang mengaitkan antara fakta dan tekhnologi ilmiah dengan cerita fiksi yang bersifat imajinatif. Cerita fiksi sains itu masih khas cerita anak, tetapi tetap saja mengandung unsur sains dan fiksi (Nurgiantoro Burhan, 2005). Cerita fiksi sains (science fiction) dapat digunakan sebagai media pembelajaran untuk menyampaikan informasi sains dan sebagai bentuk komunikasi yang digemari anak-anak serta dapat melatih kemampuan anak-anak dalam memusatkan perhatian untuk beberapa waktu terhadap suatu objek tertentu. Hal tersebut dikarenakan dengan menggunakan cerita fiksi sains dalam pembelajaran, guru dapat melibatkan penglihatan, pendengaran, gerak, dan hati anak dalam proses pembelajaran.

Penggunaan cerita fiksi sains (science fiction) sebagai media peningkatan kecerdasan naturalis tidak terlepas dari sifat-sifat dasar seorang anak yag memiliki rasa ingin tahu besar terhadap hal-hal baru, aneh, dan bersifat rahasia, sehingga dapat 
mengembangkan daya analisis dan fantasi anak. Dalam hubungannya dengan pendidikan manusia secara umum, Rosen dalam Yudha, bahwa otak manusia adalah perkakas naratif. Otak hidup dan bergerak dalam cerita (Yudha, 2007). Dengan kata lain, segala sesuatu yang disimpan dalam bentuk cerita jauh lebih bermakna bagi anak daripada segala sesuatu yang dijejalkan ke dalam otak anak hanya dalam bentuk fakta.

Dari beberapa pendapat yang telah dikemukakan di atas, dapat dideskripsikan pentingnya pengenalan alam pada anak usia dini; salah satu bentuk pembelajaran untuk anak usia dini adalah cerita fiksi sains. Dari pendapat tersebut belum ada yang berupaya meningkatkan kecerdasan naturalis bagi anak usia dini melalui cerita fiksi sains.

Berdasarkan pengamatan yang dilakukan peneliti di kelompok B1 RA Asy-Syafi Kota Tangerang yang berjumlah 12 anak, sebagian besar anak belum mampu mengenal dan menjaga lingkungan sekolah dengan baik. Hal ini terlihat dari aktivitas anak yang sering merusak tanaman di halaman sekolah seperti menginjak rumput, memukul atau merusak daun tanaman, bahkan mencabutnya. Sebagian anak juga sering mengganggu dan memukul binatang (lampiran 1). Pada penelitian ini, peneliti berusaha mencari solusi atas permasalahan tersebut dengan mengajak anak melakukan observasi, investigasi, dan eksperimen akan tanaman, hewan melalui cerita fiksi sains.

Pada penelitian ini, peneliti tertarik untuk mengetahui upaya peningkatan kecerdasan naturalis melalui cerita fiksi sains pada kelompok B1 RA Asy-Syafi Kota Tangerang. Selanjutnya bagaimana peningkatan kecerdasan naturalis dapat dilakukan melalui cerita fiksi sainspada kelompok B1 RA Asy-Syafi`Kota Tangerang.

\section{METODE}

\section{Tujuan Penelitian}

1. Mendeskripsikan bagaimana peningkatan kecerdasan naturalis melalui cerita fiksi sains pada anak di kelompok B1 RA Asy-Syafi` Kota Tangerang .

2. Mendeskripsikan apakah peningkatan kecerdasan naturalis dapat dapat ditingkatkan dengan cerita fiksi sains pada anak di kelompok B1 RA Asy-Syafi`Kota Tangerang.

\section{Tempat dan Waktu Penelitian}

Dalam penulisan ini penelitiannya dilakukan di RA Asy-Syafi Cipondoh Kota Tangerang, tepatnya Jl. Tugu Karya I Poris Plawad Utara Cipondoh Kota Tangerang. Hal ini peneliti lakukan karena di RA tersebut membutuhkan perubahan metode dalam meningkatkan kecerdasan naturalis pada anak terutama di kelompok B1. Penelitian dilakukan di bulan Mei 2019 dan penulisan hasil penelitian di bulan Juni-Juli 2019

Penelitian tindakan kelas ini dilakukan dalam dua siklus untuk melihat apakah peningkatan kecerdasan naturalis dapat dilakukan cerita fiksi sains di kelompok B1 RA Asy-Syafi` Kota Tangerang. Pada siklus I dan siklus II masing-masing 6 kali pertemuan. Dalam setiap siklusnya dilakukan dengan beberapa kegiatan yaitu dari perencanaan, pelaksanaan, pengamatan, pengumpulan data, dan refleksi, dimana pada setiap pertemuan menggunakan waktu 2 x 30 menit.

\section{Metode Penelitian}

Metode penelitian yang digunakan oleh peneliti adalah metode Penelitian Tindakan (PT), atau dikenal dengan istilah Action Research (AR). Dalam penelitian ini peneliti terjun langsung berkolaborasi dengan teman sejawat (guru kelas) bersama-sama melakukan penelitian tindakan untuk memperbaiki proses pembelajaran tersebut. 
Model penelitian tindakan yang digunakan adalah yang dikemukakan oleh Kemmis dan Mc Taggart, pemilihan model penelitian tindakan ini karena lebih mudah dipahami dan menggabungkan antara tindakan dan observasi menjadi dua hal yang tidak bisa dipisahkan dan dilakukan bersama-sama. Berikut desain yang dibuat oleh Kemmis dan McTagart:
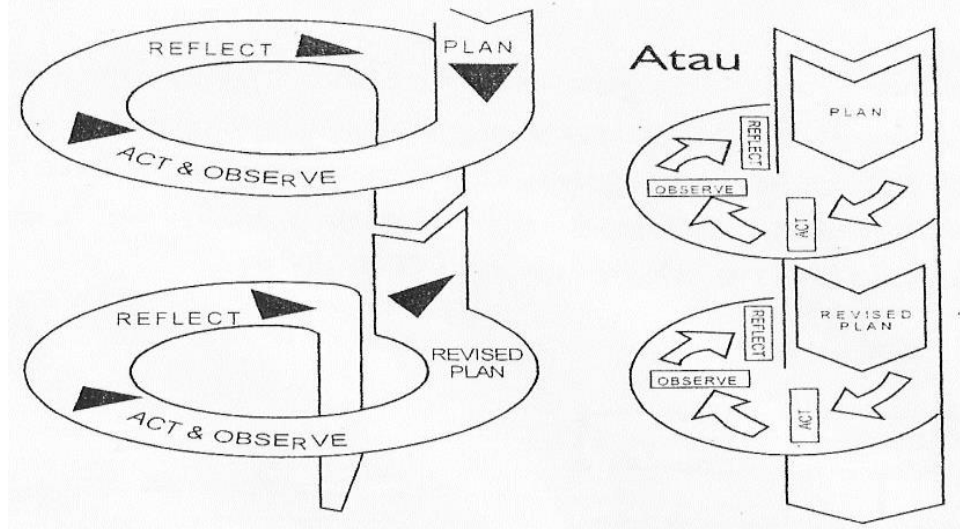

Gambar 1. Model Penelitian Tindakan (Kemmis \& McTaggart)

Jika dicermati, model yang dikemukakan Kemmis \& McTaggart pada hakekatnya berupa perangkat atau untaian yang terdiri dari empat komponen, yaitu: perencanaan, tindakan, pengamatan, dan refleksi. Keempat komponen yang berupa untaian tersebut dipandang sebagai satu siklus. Oleh karena itu, siklus yang dimaksud di sini adalah putaran kegiatan yang terdiri dari perencanaan, tindakan, pengamatan, dan refleksi. Dalam pelaksanaan penelitian, jumlah siklus bergantung kepada permasalahan yang perlu diselesaikan.

\section{Prosedur Penelitian}

Sebelum dilakukan penelitian, maka peneliti menyusun tahapan-tahapan kegiatan. Tahapan tersebut adalah.

\section{Kegiatan Pra Siklus (Pra Penelitian)}

$a$. Meminta izin pihak yayasan tentang rencana penelitian.

$b$. Melakukan observasi pra penelitian.

c. Membuat jadwal rencana penelitian.

1. Siklus I

a. Tahapan Perencanaan Tindakan (planning)

Perencanaan kegiatan cerita fiksi sains untuk meningkatkan kecerdasan naturalis yang akan dilaksanakan peneliti dan kolaborator. Perencanaan yang dilakukan meliputi persiapan bahan dan alat belajar, waktu pembelajaran, rencana kegiatan harian (RKH). Menyiapkan juga alat pengumpul data berupa lembar observasi, catatan wawancara, catatan lapangan, dan dokumentasi untuk melihat hasil pada setiap tindakan.

Peneliti dan kolaborator menentukan indikator keberhasilan yang hendak dicapai untuk meningkatkan kecerdasan naturalis dengan cerita fiksi sains melalui kegiatan observasi, investigasi, dan eksperimen terhadap tanaman, hewan, serta benda alam pada anak kelompok B1 di RA Asy-Syafi` adalah $75 \%$ setelah dilakukan tindakan.

\section{b. Tahapan Pelaksanaan Tindakan (Acting) dan Pengamatan (Observing)}

Untuk mempermudah melakukan tindakan penelitian, maka peneliti menyusun skenario pembelajaran, yaitu. 
a. Guru menyambut anak yang datang, memberi salam, menyapa, dan menanyakan keadaan anak-anak pada saat itu.

b. Memohon pertolongan Allah SWT untuk kegiatan bermain dan belajar hari ini dengan mengajak anak membaca doa belajar, murojaah Al-Quran, sholawat nab,i dan membaca asmaul husna.

c. Sebelum mulai materi, guru mengajukan pertanyaan seputar tanaman dan hewan untuk mengetahui sejauh mana pemahaman anak, atau mengulang pembelajaran kemarin.

d. Peneliti dan kolaborator mengenalkan tentang tanaman dan hewan melalui cerita fiksi sains, amati setiap perkembangannya.

e. Peneliti dan kolaborator setelah bercerita fiksi sains, berbincang-bincang tentang cerita fiksi sains yang dibacakan tadi, amati setiap perkembangannya.

f. Peneliti dan kolaborator setelah bercerita fiksi sains, mengajak anak menyayangi tanaman, hewan, dan lingkungan sekitar, amati setiap perkembangannya.

Untuk memudahkan proses berjalannya tindakan penelitian, maka peneliti membuat instrument penelitian. Instrument penelitian adalah alat yang digunakan dalam mengumpulkan data agar pekerjaannya lebih mudah dan hasilnya lebih baik, lebih cermat, lengkap, sistematis, sehingga lebih mudah diolah (Arikunto, 1996). Instrument yang digunakan untuk mengetahui pengembangan kecerdasan naturalis anak berupa lembar pengamatan yang diamati mencakup adanya dimensi-dimensi.

Pengamatan dilakukan bersamaan dengan tindakan. Pengamatan dilakukan oleh peneliti dan kolaborator. Hal ini bertujuan agar data yang dikumpulkan lebih objektif dan tidak bias. Pengamatan yang dilakukan menggunakan lembar instrumen, hasilnya digunakan sebagai bahan pertimbangan tindak lanjut siklus berikutnya jika belum mencapai target yang disepakati.

Pengamatan yang dilakukan adalah dengan mengisi lembar instrumen penelitian, dengan memberikan tanda check list $(\sqrt{ })$ pada pilihan jawaban yang sesuai. Hasil pengamatan juga dicatat dengan bentuk uraian dalam lembar catatan lapangan (CL) dengan menggunakan pendekatan peer observation (pengamatan sejawat) yaitu berdasarkan pengamatan peneliti dan kolaborator. Peneliti juga menggunakan alat bantu dokumentasi berupa foto dan kamera. Laporan keseluruhan penelitian berupa catatan lapangan (CL), catatan dokumentasi (CD) dan catatan wawancara (CW).

\section{c. Tahapan Refleksi (Reflecting)}

Pada tahapan ini, peneliti melakukan beberapa proses:

\section{a. Analisis Data}

Setelah data diambil, maka peneliti melakukan diskusi dengan teman sejawat yang melakukan kolaborasi tentang hasil yang sudah didapat. Diskusi meliputi keberhasilan, kegagalan, dan hambatan yang dijumpai pada saat melakukan tindakan.

b. Mereduksi Data

Data-data yang sudah diperoleh, kemudian dipilih yang benar-benar dibutuhkan untuk menyusun laporan hasil penelitian

c. Menyusun Langkah-Langkah Perbaikan

Setelah mendapatkan gambaran tentang permasalahan dan hambatan yang dijumpai, maka langkah selanjutnya peneliti menyusun kembali rencana kegiatan.

\section{Siklus II}

Siklus II merupakan kegiatan penyempurnaan dari siklus I, setelah dilakukan refleksi di siklus I. Siklus II juga berisi penguatan dan pengulangan materi siklus I dengan 
harapan anak-anak benar-benar memahami tujuan pembelajaran, sehingga kecerdasan naturalis anak kelompok B1 RA Asy-Syafi` Kota Tangerang dapat ditingkatkan melalui cerita fiksi sains.

\section{Kriteria Keberhasilan Tindakan}

Penelitian ini dikatakan berhasil jika $71 \%$ dari jumlah anak sudah mencapai kriteria ketuntasan perkembangan (KKP), artinya ada 8 anak dari 12 anak setelah siklus selesai mencapai kriteria ketuntasan perkembangan (KKP). Standar keberhasilan tindakan ini mengikuti standar G.E. Mills (Mills, 2003). Sedangkan pada penelitian ini disepakati oleh peneliti dan kolaborator adalah 75\%, artinya dari ada 9 anak dari 12 anak setelah siklus selesai mencapai kriteria ketuntasan perkembangan (KKP).Dengan perhitungan sebagai berikut :

$$
\begin{aligned}
\text { TCPmax } & =\sum \text { butir } \times \text { kategori } \\
& =25 \times 4 \\
& =100 \\
& =\underline{75} \times \mathrm{TCPmax} \\
& 100 \\
& =75
\end{aligned}
$$

\section{Data dan Sumber Data}

Data yang diperoleh dalam penelitian ini adalah data kuantitatif dan kualitatif. Data kuantitatif berupa skor pra intervensi dan hasil tindakan (skor) siklus, sedangkan kualitatif dilihat dari perkembangan anak saat kegiatan pembelajaran sedang berlangsung, rencana pembelajaran dalam bentuk program cerita fiksi sains, $\mathrm{RKH}$, dan data hasil observasi pelaksanaan.

Sumber data dalam penelitian ini adalah anak kelompok B1 RA Asy-Syafi Kota Tangerang, yang merupakan sumber data primer yang berjumlah 12 anak, kepala sekolah atau yayasan dapat memberikan informasi mengenai kegiatan pembelajaran, dan kolaborator yang terlihat dalam penelitian yaitu guru kelas.

\section{Teknik Pengumpulan Data}

\section{Lembar Observasi}

Peneliti melakukan pengumpulan data dengan cara melakukan observasi atau pengamatan langsung terhadap siswa. Keuntungan yang diperoleh melalui observasi adalah pengalaman yang diperoleh secara mendalam, dimana peneliti berhubungan langsung dengan objek penelitian. Melalui hubungan langsung tersebut peneliti dapat melihat apa yang terjadi sebenarnya di lapangan.

Tujuan utama observasi adalah untuk memantau proses, hasil, dan dampak perbaikan pembelajaran yang direncanakan. Hal ini, senada dengan ungkapan Nasution bahwa dalam penelitian tindakan, observasi terutama ditujukan untuk memantau proses dan dampak perbaikan yang direncanakan. Kemudian proses dan dampak yang teramati diinterpretasikan, selanjutnya digunakan untuk menata kembali langkah-langkah perbaikan (Nasution, 1996).

Jenis observasi yang peneliti gunakan dalam penelitian ini adalah observasi sistematis. Arikunto menjelaskan bahwa observasi sistematis dilakukan pengamat dengan menggunakan pedoman sebagai instrument pengamatan (Nasution, 1996). Pedoman observasi berisi sebuah daftar jenis kegiatan yang mungkin timbul dan akan diamati. Dalam proses observasi pengamat memberikan skala penilaian (rating scale) pada pertanyaan yang telah disiapkan sebelumnya. Pengamatan yang dilakukan dengan mengisi lembar instrumen penelitian, dengan memberikan tanda check list $(\sqrt{ })$ pada pilihan jawaban yang sesuai. 
Formatif: Jurnal Ilmiah Pendidikan MIPA

Vol. 9, No. 4, December 2019, pp. 339-352

p-ISSN: 2088-351X

e-ISSN: 2502-5457

DOI: http://dx.doi.org/10.30998/formatif.v9i4.4140

\section{Catatan Wawancara $(\mathrm{CW})$}

Wawancara yang akan dilakukan oleh peneliti sendiri dengan maksud untuk menjaring data tentang pelaksanaan tindakan, pandangan dan pendapat siswa yang dijadikan objek penelitian. Wawancara yang dilakukan adalah wawancara terstruktur yang jawabannya bersifat terbuka. Isi pertanyaan wawancara dalam penelitian ini berkenaan dengan kecerdasan naturalis.

\section{Catatan Lapangan (CL)}

Catatan lapang dipakai untuk mencatat proses kegiatan belajar, baik yang didengar, dilihat dan dirasakan oleh peneliti dan kolaborator dalam upaya pengumpulan data. Catatan lapang juga digunakan untuk refleksi kegiatan belajar selanjutnya.

\section{Studi Dokumentasi}

Studi dokumentasi sebagai tehnik pengumpulan data pada penelitian ini adalah dokumentasi-dokumentasi yang peneliti ambil pada saat melakukan penelitian di RA Asy-Syafi` Kota Tangerang, dapat berupa foto, video, rekaman suara atau studi literatur hasil penelitian orang lain.

\section{HASIL DAN PEMBAHASAN}

Hasil

Penelitian dilakukan 2 siklus, setiap siklus dilaksanakan 6 kali tindakan. Setiap siklus terdiri dari perencanaan, tindakan, observasi, dan refleksi. Keempat tahapan tersebut adalah satu siklus putaran yang dilakukan berulang sehingga tujuan penelitian tercapai dan fokus masalah penelitian dapat teratasi. Siklus yang dilalui harus mencapai tingkat keberhasilan tindakan. Tingkat keberhasilan tindakan yang digunakan peneliti adalah kesepakatan bersama antara peneliti dan kolaborator, yaitu Tingkat Capaian Perkembangan (TCP) sebesar $75 \%$. Nilai ini merujuk pada teori Mills yang menyatakan bahwa tingkat keberhasilan penelitian dinyatakan berhasil apabila mencapai peningkatan sebesar $71 \%$ dari jumlah keseluruhan responden (siswa). Bila Tingkat Capaian Perkembangan (TCP) sebesar 75\% tidak tercapai di siklus I maka penelitian dilanjutkan di siklus II dengan melakukan beberapa perbaikan dan penguatan.

Pelaksanaan tindakan siklus II ini dilakukan sebagaimana yang direncanakan antara peneliti dan kolaboran saat releksi di siklus I. Pada Siklus II keterampilan guru dalam bercerita fiksi sains juga benar-benar diusahakan agar mampu meningkatkan kecerdasan naturalis anak yang optimal. Tindakan dan pengamatan dilakukan secara bersamaan pada saat penggunaan cerita fiksi sains untuk mengetahui apakah tindakan sudah sesuai yang direncanakan sebelumnya. Hasil pengamatan peneliti bersama kolaborator menunjukan bahwa selama pelaksanaan tindakan, kegiatan penggunaan cerita fiksi sains untuk peningkatan kecerdasan naturalis anak berjalan baik, hal ini terlihat dari indikator kecerdasan naturalis anak seperti anak sudah mampu mengenali tanaman dengan menyebutkan nama sayuran dan bagian tubuh tumbuhan, mampu mengenali hewan dengan menyebutkan nama hewan peliharaan dan nama hewan pada cerita atau gambar. Sebagian besar anak juga sudah mampu menyebutkan ciriciri tanaman dan hewan, mampu mengajukan dan menjawab beberapa pertanyaan tentang tanaman dan hewan serta mampu menyebutkan tahapan percobaan sederhana tentang hewan atau tanaman.

Selain mengamati pelaksanaan kegiatan penggunaan cerita fiksi sains, peneliti dan kolaborator juga melakukan pengamatan pada setiap anak. Pengamatan yang dilakukan oleh peneliti dan kolaborator dijadikan satu dalam catatan lapangan. 
Pembelajaran pada siklus II dengan kegiatan yang sudah direncanakan dan pengunaan cerita fiksi sains untuk meningkatkan kecerdasan naturalis anak dilakukan penuh oleh peneliti dan dibantu guru kelas sebagai kolaborator. Tahap elaksanaan tindakan ini menerapkan kegiatan sesuai dengan perencanaan yang telah disusun oleh peneliti dan kolaborator. Pada tahap ini dilakukan enam kali pertemuan.

Tabel 1. Rekap Data Kecerdasan Naturalis Anak Kelompok B1 RA Asy-Syafi Tahun Ajaran 2018-2019 Prasiklus, Siklus I dan Siklus II

\begin{tabular}{cccccccc}
\hline No & Nama & \multicolumn{2}{c}{ Prasiklus } & \multicolumn{2}{c}{ siklus I } & \multicolumn{2}{c}{ Siklus II } \\
& Anak & Prasiklus \% & Katagori & Siklus I \% & Katagori & Sikus II \% & Katagori \\
\hline 1 & ASA & 37 & BB & 63 & BSH & 88 & BSB \\
2 & AKH & 38 & BB & 65 & BSH & 88 & BSB \\
3 & CZS & 35 & BB & 61 & MB & 83 & BSB \\
4 & CAC & 52 & MB & 78 & BSH & 98 & BSB \\
5 & FSC & 35 & BB & 63 & BSH & 82 & BSB \\
6 & MAR & 41 & BB & 66 & BSH & 87 & BSB \\
7 & MES & 49 & MB & 73 & BSH & 84 & BSB \\
8 & MFH & 44 & MB & 72 & BSH & 89 & BSB \\
9 & ZA & 34 & BB & 60 & MB & 79 & BSH \\
10 & QF & 49 & MB & 70 & BSH & 87 & BSB \\
11 & RS & 51 & MB & 75 & BSH & 86 & BSB \\
12 & ZR & 45 & MB & 76 & BSH & 85 & BSB \\
Rata-rata & $\mathbf{4 2 , 5 0}$ & BB & $\mathbf{6 8 , 5 0}$ & BSH & $\mathbf{8 6 , 3 3}$ & BSB \\
\hline
\end{tabular}

Konversi Skor Kecerdasan Naturalis

25,00-43,75 : Belum Berkembang (BB)

43,76-62,50 : Mulai Berkembang (MB)

62,51-81,25 : Berkembang Sesuai Harapan (BSH)

$81,26-100$ : Berkembang Sangat Baik (BSB)

Hasil tindakan melalui media cerita fiksi sains dalam meningkatkan kecerdasan naturalis rata-rata anak kelompok B1 RA Asy-Syafi tahun ajaran 2018/2019 pada siklus II diperoleh dari 12 orang anak mengalami peningkatan dari pra siklus ke siklus I dan siklus II. Pada pra siklus persentase kecerdasan naturalis anak mencapai rata-rata sebesar 42,5\% (BB), pada siklus I 68,5\% (BSH) dan pada siklus II persentase kecerdasan naturalis anak mencapai rata-rata sebesar $86,33 \%$ (BSB). Peningkatan kecerdasan naturalis anak dari pra siklus ke siklus I adalah $26 \%$, dari siklus I ke siklus II adalah 17,83\%, dan dari pra siklus ke siklus II sebesar $43,83 \%$. Berdasarkan hasil dari siklus II yang merupakan kelanjutan dan perbaikan dari siklus I maka dapat diketahui bahwa kecerdasan naturalis anak sudah berada pada kategori berkembang sangat baik (BSB). Hal ini, berarti bahwa kecerdasan naturalis anak kelompok B1 RA Asy-Syafi' Cipondoh Kota Tangerang tahun ajaran 2018/2019 mengalami peningkatan melalui cerita fiksi sains. 
Formatif: Jurnal Ilmiah Pendidikan MIPA

Vol. 9, No. 4, December 2019, pp. 339-352

p-ISSN: 2088-351X

e-ISSN: $2502-5457$

DOI: http://dx.doi.org/10.30998/formatif.v9i4.4140

\section{Pembahasan}

Kegiatan pembelajaran dalam rangka peningkatan kecerdasan naturalis di RA Asy-Syafi Kota Tangerang tahun ajaran 2018-2019 dilaksanakan dalam 2 siklus, peneliti membuat perencanaan kegiatan bersama kolaborator dan disepakati bahwa siklus I dilaksanakan sebanyak 6 kali pertemuan dengan peningkatan kecerdasan naturalis melalui cerita fiksi sains. Hasil perencanaan yang telah dibuat oleh peneliti yang disetujui kolaborator lalu digunakan dalam setiap pertemuan. Pada tahap persiapan sebelum persiapan proses kegiatan belajar mengajar peneliti dan kolaborator mempersiapkan segala sesuatu yang digunakan pada saat penelitian seperti alat dan media yang telah dipersiapkan.

Berdasarkan hasil tindakan yang dilakukan oleh peneliti, baik guru maupun anakanak belajar cerita fiksi sains dengan perasaan senang. Penggunaan cerita fiksi sains dalam pembelajaran mampu meningkatkan kecerdasan naturalis diharapkan anak akan menyayangi tanaman dan hewan yang ada disekelilingnya yang pada akhirnya mampu menjaga kelestarian bumi. Hal tersebut senada dengan yang disampaikan Nurgiantoro, salah satu media pembelajaran yang dapat digunakan guru untuk meningkatkan kecerdasan naturalis pada anak adalah cerita fiksi sains (science fiction), yang merupakan media pembelajaran berbentuk grafis berisi materi pembelajaran sains dan temanya disesuaikan dengan upaya peningkatan kecerdasan naturalis yang dikemas dalam sebuah alur cerita secara menarik. Cerita Fiksi sains (science fiction) adalah adalah sebuah fiksi yang mengaitkan antara fakta dan tekhnologi ilmiah dengan cerita fiksi yang bersifat imajinatif. Cerita fiksi sains itu masih khas cerita anak, tetapi tetap saja mengandung unsur sains dan fiksi (Nurgiantoro Burhan, 2005). Cerita fiksi sains (science fiction) dapat digunakan sebagai media pembelajaran untuk menyampaikan informasi sains dan sebagai bentuk komunikasi yang digemari anak-anak dapat melatih kemampuan anak-anak dalam memusatkan perhatian untuk beberapa waktu terhadap suatu objek tertentu. Hal tersebut dikarenakan dengan menggunakan cerita fiksi sains dalam pembelajaran, guru dapat melibatkan penglihatan, pendengaran, gerak, dan hati anak dalam proses pembelajaran.

Anak mengalami peningkatan kecerdasan naturalis pada indikator mengenali tanaman, hal ini diamati oleh peneliti dan guru ketika anak-anak mampu menyebutkan nama sayuran dan mampu menyebutkan nama bagian tubuh tanaman. Anak mengalami peningkatan kecerdasan naturalis pada indikator mengenali hewan. Hal ini diamati oleh peneliti dan guru ketika anak-anak mampu menyebutkan nama hewan peliharaan dan nama hewan dalam cerita fiksi sains. Anak mengalami peningkatan kecerdasan naturalis pada indikator menyebutkan ciri-ciri tanaman. Hal ini diamati oleh peneliti dan guru ketika anak-anak mampu menyebutkan ciri-ciri tanaman dalam cerita fiksi sains. Anak mengalami peningkatan kecerdasan naturalis pada indikator menyebutkan ciri-ciri hewan. Hal ini diamati oleh peneliti dan guru ketika anak-anak mampu menyebutkan ciri-ciri hewan dalam cerita fiksi sains. Anak mengalami peningkatan kecerdasan naturalis pada indikator mengajukan pertanyaan tentang tanaman. Hal ini diamati oleh peneliti dan guru ketika anak-anak mampu mengajukan pertanyaan tentang tanaman dalam cerita fiksi sains. Anak mengalami peningkatan kecerdasan naturalis pada indikator mengajukan pertanyaan tentang hewan. Hal ini diamati oleh peneliti dan guru ketika anak-anak mampu mengajukan pertanyaan tentang hewan dalam cerita fiksi sains. Anak mengalami peningkatan kecerdasan naturalis pada indikator menjawab pertanyaan tentang tanaman. Hal ini diamati oleh peneliti dan guru ketika anak-anak mampu menjawab pertanyaan tentang tanaman dalam cerita fiksi sains. Anak mengalami peningkatan kecerdasan naturalis pada indikator menjawab pertanyaan tentang hewan. Hal ini diamati oleh peneliti dan guru ketika anak-anak mampu menjawab pertanyaan tentang hewan dalam 
cerita fiksi sains. Anak mengalami peningkatan kecerdasan naturalis pada indikator menyebutkan tahapan percobaan sederhana. Hal ini diamati oleh peneliti dan guru ketika anak-anak mampu menyebutkan tahapan percobaan sederhana dalam cerita fiksi sains.

Hasil tindakan melalui media cerita fiksi sains dalam meningkatkan kecerdasan naturalis rata-rata anak kelompok B1 RA Asy-Syafi tahun ajaran 2018-2019 pada siklus II diperoleh dari 12 orang anak mengalami peningkatan dari pra siklus ke siklus I dan siklus II. Pada pra siklus persentase kecerdasan natralis anak mencapai rata-rata sebesar 42,5\% (BB), pada siklus I 68,5\% (BSH) dan pada siklus II persentase kecerdasan natralis anak mencapai rata-rata sebesar 86,33\% (BSB). Peningkatan kecerdasan naturalis anak dari pra siklus ke siklus I adalah $26 \%$, dari siklus I ke siklus II adalah $17,83 \%$, dan dari pra siklus ke siklus II sebesar 43,83\%.

\section{PENUTUP}

Peningkatan kecerdasan naturalis anak kelompok B1 RA Asy-Syafi`Cipondoh Kota Tangerang tahun pelajaran 2018/2019 melalui cerita fiksi sains menunjukkan hasil analisis rata-rata tingkat capaian perkembangan pada pra siklus sebesar $42,5 \%$ dengan kategori belum berkembang (BB), pada siklus I naik menjadi 68,5\% dengan kategori berkembang sesuai harapan (BSH) dan pada siklus II persentase kecerdasan naturalis anak mencapai rata-rata sebesar 86,33\% dengan kategori berkembang sangat baik (BSB). Penelitian ini dikatakan berhasil karena telah mencapai tingkat capaian perkembangan (TCP) yang ditetapkan sebelumnya antara peneliti dan kolaborator sebesar $75 \%$. Kecerdasan naturalis dapat ditingkatkan dengan cerita fiksi sains yaitu science fiction yang merupakan media pembelajaran berbentuk grafis berisi materi pembelajaran sains dan temanya disesuaikan dengan upaya peningkatan kecerdasan naturalis yang dikemas dalam sebuah alur cerita secara menarik, tokohn, dan alur ceritanya dapat berupa khayalan pengarang atau sesungguhnya.

\section{DAFTAR PUSTAKA}

Al-Jafar, A. (2016). The art of storytelling for cross cultural understanding. International Journal of Early Childhood. https://doi.org/36(1), 35-48. DOI: 10.1007/BF03165939

Apriyansyah, C. (2016). Peningkatan Kecerdasan Naturalis Melalui Penggunaan Media Realita.

Aqid, Z., \& dkk. (2009). Penelitian Tindakan kelas untuk Guru SD dan TK. (Yrama Widya, Ed.). Bandung.

Arikunto, S. (1996). Prosedur Penelitian suatu Pendekatan Praktek. (R. Cipta, Ed.). Jakarta.

Arikunto, S., Suhardjono, \& Supardi. (2015). Penelitian Tindakan Kelas. (PT. Bumi Aksara, Ed.) (Revisi). Jakarta.

Armstrong, T. (2009). Multiple Intelligences in the Classroom. (Alexandria, Ed.) (3rd ed.). Virginia.

Baum, Susan, Julie Viens, B. S. (2005). Multiple Intelegences in the Elementary Classroom: a teacher's Toolkit. (T. C. Press, Ed.). New York. Retrieved from https://www.academia.edu/35128451/Multiple_Intelligences_in_the_Elementary_ Classroom_A_Teachers_Toolkit_ 
Burhan, N. (2009). Penilaian dalam Pengajaran Bahasa dan Sastra. (BPFE, Ed.) (3rd ed.). Yogyakarta.

Cremin, T., \& et al. (2018). Storytelling and story-acting: co-construction in action. Journal of Early Childhood

Research. https://doi.org/doi.org/10.1177/1476718X17750205

Cutter-Mackenzie, A., Edwards, S., Moore, D., \& Boyd, W. (2014). Young Children's Play and Environmental Education in Early Childhood Education, 9-25. https://doi.org/10.1007/978-3-319-03740-0

Eberle, S. G. (2011). Playing with the Multiple Intelligences: How Play Helps Them Grow. American Journal of Play, 4(1), 19-51. Retrieved from http://www.journalofplay.org/sites/www.journalofplay.org/files/pdf-articles/4-1article-eberle-multiple-intelligences.pdf

Eshach, H., \& Fried, M. N. (2005). Should science be taught in early childhood? Journal of Science Education and Technology, 14(3), 315-336. https://doi.org/10.1007/s10956-005-7198-9

Gardner, H. (1994). Frames of Mind: The Theory of Multiple Intelligences. (B. Books, Ed.). New York.

Gunawan, A. W. (2012). Born to be a Genius Kunci Mengangkat Harta Karun dalam Diri Anak. (Gramedia, Ed.). Jakarta.

Handini, M. C. (n.d.). Metodologi Penelitian untuk Pemula. (FIP Press, Ed.). Jakarta.

Hartono. (2005). Pelatihan Pelatihan Penulisan Cerita atau Dongeng dan Teknik Penyajiannya sebagai Media Pembelajaran Budi Pekerti bagi Guru Taman Kanakkanak Kodya Yogyakarta. (U. Press, Ed.). Yogykarta.

Heristi, Y. (2013). Peningkatan Kecerdasan Naturalis Melalui Metode Inquiri. Jurnal Untan, PG PAUD, FKIP Universitas Tanjungpura. Retrieved from https://docplayer.info/52248792-Peningkatan-kecerdasan-naturalis-melaluimetode-inquiri-pada-anak-usia-5-6-tahun-di-tk-al-rahman-ketapang-artikelpenelitian.html

Hoerr, T. R. (2010). Multiple Intelligences Classroom. (J. Bass, Ed.) (2nd ed.). San Fransisco.

Hopkins, D. (2002). A Teacher's guide to Classroom Research. (Open University Press, Ed.). Buckingham.

Isbell, R., \& et al. (2004). The effects of storytelling and story reading on the oral language complexity and story comprehension of young children. Early Childhood Education Journal, 32(3), 157-163.

Johnson, K. (2014). Creative connecting: Early childhood nature journaling sparks wonder and develops ecological literacy. International Journal of Early Childhood Environmental Education, 2(1), 126-139. Retrieved from http://proxy.library.vcu.edu/login?url=http://search.proquest.com/docview/182654 4307? accountid $=14780$

Jones, C. H. dan C. (2005). Literacy the Creative Curriculum Approach. Washington: Teaching Strategies, Inc.

Juniarti, Y. (2015). Peningkatan kecerdasan naturalis melalui metode kunjungan lapangan. Jurnal Pendidikan AUD UNJ, 9(2), 267-284.

Kementerian Pendidikan dan Kebudayaan. (2014). Peraturan Menteri Pendidikan dan Kebudayan Nomor 137 Tahun 2014 tentang Standar Pendidikan Anak Usia Dini.

Kemmis, S., \& Taggart, R. M. (1990). The Action Research Planner. (D. University, Ed.). Australia.

Kiewra, C., \& Veselack, E. (2016). Playing with nature: Supporting preschoolers' creativity in natural outdoor classrooms christine kiewra dimensions educational 
research foundation, USA Ellen Veselack. The International Journal of Early Childhood Environmental Education, 4(1), 71-96.

Kunandar. (2008). Langkah Mudah Penelitian Tindakan Kelas sebagai Pengembangan Profesi Guru. (Rajagrafindo Persada, Ed.). Jakarta.

Kusumah, W., \& Dedi. (2012). Mengenal Penelitian Tindakan Kelas. (PT Indeks, Ed.) (5th ed.). Jakarta.

Lexy J Moleong. (2000). Metodologi Penelitian Kualitatif. (Rosdakarya, Ed.). Bandung.

Madya, S. (2011). Penelitian Tindakan (Action Research) Teori dan Praktek. (Alfabet, Ed.). Bandung.

Marliawita, D., Sasmiati, \& Risyak, B. (2015). Hubungan penerapan metode bercerita dengan kemampuan mengungkapkan bahasa. Jurnal Fakultas Keguruan Dan Ilmu Pendidikan Bandar Lampung, (1113054017).

Masdiono, T. (1999). Keberadaan tema fantasi dan fiksi sains dalam ilustrasi. Nirmana, $1(1), 55-59$.

Matre, S. Van. (2018). Multiple Intelligences Smart Card. Nature Journal.

Maulisa, R., Israwati, \& Amri, A. (2016). Meningkatkan kecerdasan naturalis anak melalui media bahan alam. Jurnal Ilmiah Mahasiswa PAUD, 1(1), 1-14.

Mertler, C. A. (2009). Action Research. (S. P. Inc., Ed.). California.

Miles, M. B., \& Huberman, A. M. (1992). Analisis Data kualitatif. (U. Press, Ed.). Jakarta.

Mills, G. E. (2003). Action Research: A Guide for the Teacher Researcher. (P. Education, Ed.) (5th ed.). USA.

Moeslichatoen. (2004). Metode Pengajaran di TK. (R. Cipra, Ed.) (2nd ed.). Jakarta.

Mohamad Surya. (2004). Psikologi Pembelajaran dan Pengajaran. Bandung: Pustaka Bani Quraisy.

Morrisonn, G. S. (2012). Dasar-Dasar Pendidikan Anak Usia Dini PAUD. (P. Indeks, Ed.) (5th ed.). Jakarta.

Mulyadi, S. (2014). Sekolah Anak-Anak Juara Berbasis Kecerdasan Jamak dan pendidikan Berkeadilan. (Kaifa, Ed.). Bandung.

Mulyasa. (2012a). Manajemen Paud (1st ed.). Bandung: Remaja Rosdakarya.

Mulyasa, H. E. (2012b). Praktik Penelitian Tindakan Kelas. (PT Remaja Rosdakarya, Ed.). Bandung.

Nasution. (1996). Penelitian Pendidikan. (Remaja Rosda Karya, Ed.). Bandung.

Naylor, J. (2016). Five have a leadership adventure: Exploring childhood fictional influences on the construction of self as a leader. Journal of Health Organisation and Management. https://doi.org/10.1108/14777261011070484

Ni Made Sri Astuti Nugraha, A. A. I. N. M., \& Tika, N. (2014). Penggunaan metode bercerita dengan media gambar dalam upaya meningkatkan kemampuan berbahasa dan sikap mandiri anak kel A TK Negri Pembina Bangli TA 2012/2013. E-Journal Program Pascasarjana Universitas Pendidikan Ganesha Program Studi Pendidikan Dasar, 4.

Nurgiantoro Burhan. (2005). Sastra Anak: Pengantar Pemahaman Dunia Anak. Yogyakarta: Gajah Mada University press.

Nurgiyantoro, B. (2004). Sastra Anak: Persoalan Genre. Journal.ugm.ac.id, 16(2), 107108. https://doi.org/10.22146/jh.v16i2.811

O’Byrne, W. I., Stone, R., \& White, M. (2018). Digital storytelling in Early Childhood: Student Illustrations Shapping Soscial Interactions. Journal Interactive Digital Technologies and Early Childhood.

Omih. (2017). Penerapan metode bercerita dalam upaya meningkatkan kemampuan menyimak cerita rakyat pada siswa kelas V SDN Panyingkiran 3 Kabupaten 
Sumedang. MPD, 8(1), 60-69.

Papadimitriou, E., Kapaniaris, A., Zisiadis, D., \& Kalogirou, E. (2013). Digital storytelling in kindergarten: An alternative tool in children's way of expression. Mediterranean Journal of Social Sciences, 4(11), 389-396. https://doi.org/10.5901/mjss.2013.v4n11p389

Preradovic, N. M., Lesin, G., \& Boras, D. (2016). Digital education review. Digital Education Review, 0(30), 94-105. Retrieved from http://revistes.ub.edu/index.php/der/article/view/16087

Rampan, K. L. (1999). Aliran-Jenis Cerita Pendek. Jakarta: Balai Pustaka.

Roberts, A. (2006). The History of Science Fiction. England: PALGRAVE MACMILLAN.

Rocmah, L. I., \& Sidoarjo, U. M. (2016). Peningkatan kecerdasan naturalis melalui bermain messy play terhadap anak usia dini. Jurnal Pedagogia, x(1), 47-56.

Rossa, V. O., Nasirun, N., \& Yulidesni, Y. (2014). Optimalisasi Kecerdasan Naturalis Anak Usia Dini Melalui Pembelajaran Sains Dengan Media Boneka Horta (Penelitan Tindakan Kelas Di Kelompok B2 Tk Tunas Harapan Kota Bengkulu).

Sachs, J., Mardell, B., \& Boni, M. (2014). Storytelling, story acting, and literacy in the Boston Public Schools. American Journal of Play, 6(2).

Sadiman, A. (2008). Media Pendidikan Pengertian, Pengembangan, dan Pemanfaatannya. (P. R. Persada, Ed.).

Sardi, N. N., Jampel, A. A. I. N. M., \& Nyoman. (2013). Pengaruh Pembelajaran dengan Teknik Bercerita Dongeng Terhadap Kemampuan Berbahasa dan Motivasi Anak Kelompok B TK Kunti II Dalung. Jurnal Universitas Negeri Surabaya.

Setiawati, N. (2018). Story Telling: Pengertian, Tujuan, Dan Generic Structure Dalam Bahasa Inggris Beserta Contohnya. IBI. Retrieved from https://www.ilmubahasainggris.com/

Setioningrum, R. (2014). Optimalisasi Kecerdasan Naturalis melalui Metode Discovery dalam Pembelajaran Anak Usia Dini.

Sharmin, S. (2015). Early childhood storytelling development and gender impact. Journal of Education and Social Sciences, 1, 36.

Sholehuddin. (2007). Ilmu \& aplikasi pendidikan. (I. B. Utam, Ed.) (4th ed.). Bandung.

Siahaan, Amiruddin dan Hidayat, N. (2014). Hadis-Hadis tentang Peserta Didik. Jurnal Pendidikan Islam, 8(April), 1-17. https://doi.org/10.1186/s12711-015-0169-6

Slafin, R. E. (2011). Psikologi pendidikan: teori dan praktik jilid 1. (Indeks, Ed.). Jakarta.

Stringer, E. T. (2007). Action Research Third Edition. (S. Publication, Ed.) (3rd ed.). California.

Sukardi. (2015). Sukardi, Metode Penelitian Pendidikan Tindakan Kelas: Implementasi dan Pengembangan. (P. B. Aksara, Ed.). Jakarta.

Susilo. (2009). Prinsip dan Teori Penelitian Pendidikan. (Poliyama Widya Pustaka, Ed.). Jakarta.

Suyadi. (2010). Psikologi Belajar PAUD. (Pedagogik, Ed.). Yogyakarta.

Suyadi, \& Ulfah, M. (2017). Konsep Dasar Paud (6th ed.). Bandung: Remaja Rosdakarya. Retrieved from https://rosda.co.id/paud/426-manajemen-paud.html

Weinhardt, M. (2013). 6 Activities To Strengthen Children's Nature-Smarts. Nature Journals Published. Retrieved from http://growingwithyourchild.com/6-activitiesto-strengthen-childrens-nature-smarts/

Wright, C., Diener, M. L., \& Kemp, J. L. (2013). Storytelling dramas as a community building activity in an early childhood classroom. Early Childhood Education Journal, 41(3), 197-210. https://doi.org/10.1007/s10643-012-0544-7

Yanuarsari, R., \& Muchtar, H. S. (2016). Improving early childhood teachers' skills 
Formatif: Jurnal Ilmiah Pendidikan MIPA

Vol. 9, No. 4, December 2019, pp. 339-352

p-ISSN: 2088-351X

e-ISSN: 2502-5457

DOI: http://dx.doi.org/10.30998/formatif.v9i4.4140

through story telling workshop people. International Journal of Social Science, 2.

Yasbiati, Giyartini, R., \& Lutfiana, A. (2017). Upaya meningkatkan kecerdasan naturalis melalui kegiatan bercocok tanam di Bambim Al-Abror Kecamatan Mangkubumi Kota Tasikmalaya, 1(2), 203-213.

Yati, M., Wahyuni, S., \& Islaeli, I. (2017). Pengaruh story telling terapi bermain terhadap tingkat kecemasan pada anak-anak pra sekolah di Rumah Sakit Umum Buton. The Journal of Acute and Critical Care.

Yaumi, M. (2012). Pembelajaran Berbasis Multiple Intelegences. (D. Rakyat, Ed.). Jakarta.

Yaumi, M., \& Ibrahim, N. (2013). Pembelajaran Berbasis Kecerdasan Jamak. (Prenadamedia, Ed.). Jakarta.

Yudha, A. (2007). Cara Pintar Mendongeng. Bandung: Mizan. 